\title{
Peningkatan Kualitas Sulam Koto Gadang Kabupaten Agam Sumatera Barat Melalui Pengembangan Desain Produk Dan Motif Untuk Mendukung Industri Kreatif
}

\author{
Ranelis $^{1}$, Rahmad Washinton ${ }^{2}$, Kendall Malik $^{3}$, Desi Trisnawati ${ }^{4}$ \\ 1.2.3.4Program Studi Kriya Seni, Fakultas Seni Rupa dan Desain, Institut Seni Indonesia Padangpanjang \\ J1. Bahder Johan, Padangpanjang, 82077, Indonesia \\ ranelis.nel@gmail.com
}

Penelitian berjudul “Peningkatan Kualitas Kerajinan Sulam Koto Gadang Melalui Pengembangan Desain Produk dan Motif Guna Mendukung Industri Kreatif” ini, bertujuan untuk meningkatkan kemampuan perajin sulam dalam membuat dan mengembangkan desain motif dan produk yang kreatif dan inovatif sesuai selera pasar dan dengan harga yang lebih terjangkau. Mengoptimalkan potensi sulam Koto Gadang sabagai salah satu produk unggulan masyarakat Koto Kadang, agar dapat menjadi produk yang berkualitas dan memiliki ciri khas daerah. Metode yang digunakan adalah eksperimen, prosedur penelitian yang dilakukan adalah dengan cara eksplorasi dan perancangan. Eksplorasi bertujuan untuk menemukan idea atau konsep melalui penggalian data dan studi pustaka, pengamatan dan wawancara. Data - data yang telah dikumpulkan diolah dan dianalisis secara kualitatif kemudian disajikan secara verbal, yang menjadi dasar dalam melakukan eksperimen perancangan. Perancangan adalah perwujudan ide dan konsep hasil eksplorasi ke dalam rancangan-rancangan desain busana, perlengkapan busana, dan produk cenderamata. Hasil penelitian ini menghasilkan busana kerja wanita, busana muslim pria, pelengkap busana wanita, pelengkap busana pria dan produk cenderamata. Penelitian ini juga menghasilkan empat desain motif yang akan diterapkan pada masing-masing produk yaitu motif siriah gadang, pucuak rabuang, itiak pulang patang, bunga mawar dan itiak lado hijau. Motif ini disusun sedemikian rupa dengan melakukan pengulangan- pengulangan motif yang diletakkan sesuai dengan bentuk produk yang dibuat.

Kata kunci: sulam koto gadang, bentuk, desain, produk.

\section{Improving The Quality Of Koto Gadang Embroidery Through Product Design And Motive Development To Supportcreative Industry}

This research entitled "Improving the Quality of Koto Gadang Embroidery Through Product Design and Motifs Development to Support Creative Industries", aims to optimize the potential of Koto Gadang embroidery as one of the superior products of the Koto Gadang community, so that it can become a quality product that has distinctive characteristics not owned by other regions. The method used is experimental, the research procedure carried out is by exploration and design. Exploration aims to find ideas or concepts through data extraction and literature studies, observations and interviews. The data that has been collected is processed and analyzed qualitatively then presented verbally, which becomes the basis of conducting design experiments. The design is the embodiment of the ideas and concepts produced by exploration into the designs of clothing, household and souvenir. The results of this study resulted in women's work clothes, men's Muslim clothing, complementary women's clothing, complementary men's clothing and souvenir products. This study also produced four motif designs that will be applied to each product, namely siriahgadang motif, pucuakrabuang, itiakpulangpatang, bungamawar and itiakladohijau. This motif is arranged in such a way by repeating motifs that are placed in accordance with the form of the product being made.

Keyword : embroidery koto gadang, motifs, design, product

Proses Review : 1 - 20 Agustus 2019, Dinyatakan Lolos: 22 Agustus 2019 


\section{PENDAHULUAN}

Pemerintah Indonesia mencanangkan tahun 2009 sebagai tahun industri kreatif. Karena Indonesia punya peluang besar dalam mengembangkan industri kreatif. Seperti yang dijelaskan oleh presiden Bambang Susilo Yudoyono (suara Karya, 3 Januari 2009), industri kreatif selain mampu menggerakkan roda perekonomian sekaligus bisa mengenalkan seni budaya Indonesia ke manca negara, terutama produk-produk kreatif yang memanfaatkan nilai budaya, warisan pusaka, dan nilai-nilai lokal. Pandangan ini menguatkan keyakinan akan pentingnya mengangkat seni budaya lokal tradisional dan ornamen tradisional sebagai sumber ide atau tema dalam produk industri kreatif, supaya dapat bertahan hidup dan berkembang di tengah pergaulan seni budaya global adalah dari sektor kerajinan sulaman. Salah satu sentral kerajinan sulam yang telah lama berkembang di Sumatera Barat adalah sulaman di Koto Gadang. Hampir seluruh rumah yang ada di Koto Gadang para wanitanya membuat kain sulam.

Sulaman Koto Gadang memiliki ciri khas tersendiri, baik dari segi teknik menghias, yang terkenal dengan sulaman suji cair (tusuk pipih) dan tusuk kapalo samek (kepala peniti), maupun motif yang ditampilkan pada kain sulaman. Namun, dari penelitian awal diketahui meskipun sulaman Koto Gadang tergolong unik dari segi tekniknya namun, dari segi bentuk produk, motif dan fungsinya masih sangat terbatas pada perlengkapan adat yaitu selendang pengantin, wanita yang baru menikah maupun wanita yang sudah tua. Tempat rokok pengantin laki-laki dan baju terawai. Bentuk motif yang dihasilkan masih bentuk motif yang sama yang dibuat secara turun temurun dan berdasarkan kreasi perajin yaitu motif flora berupa motif bunga dan daun. kerajinan sulam sebagai produk sosial dan modal dasar dalam melahirkan perubahan dan dampak bagi dimensi kehidupan manusia, penulis bersama dengan tim melakukan penelitian dalam bentuk penelitian terapan dengan melakukan inovasi berupa pengembangan desain motif dan produk dengan cara mengkreasikan motif Minangkabau sebagai ciri khasnya.

Penelitian yang berjudul "Peningkatan Kualitas Produk Sulam Koto Gadang Melalui Pengembangan Desain Motif Untuk Mendukung Industri Kreatif'. Bertujuan untuk mengoptimalkan potensi sulaman Koto Gadang sebagai salah satu produk unggulan masyarakat Koto Gadang agar dapat menjadi produk yang memiliki ciri khas yang tidak dimiliki oleh daerah lain. Sehingga konsumen tidak akan jenuh dengan produk lokal yang selama ini terkesan sangat monoton terutama dalam penerapan desain motif atau ragam hias yang pada akhirnya dapat menjadi produk unggulan yang berprospek menjadi komoditas yang mampu mencerminkan kelokalan nagari Koto Gadang, original, unik, dan prospektif serta siap diproduksi secara luas dalam industri kreatif. Dalam mengkaji pengembangan desain produk dan motif sulam ini menggunakan kajian strategi desain yang terdiri dari strategi desain dan strategi inovasi yang dikemukakan oleh Agus Sachari, dan teori lain yang terdiri dari daya tarik keindahan produk, bahan-bahan yang digunakan, alat yang dipakai, teknik pembuatan dan keaslian produk. Kontribusi dari penelitian ini adalah diharapkan dengan dilakukan penelitian ini produk sulam yang dihasilkan oleh perajin akan lebih bervariasi dengan bentuk dan motif yang baru berupa busana kerja wanita, busana muslim pria dan wanita. Pelengkap busana / asesoris untuk busana seperti tas, dompet, jilbab, peci. Produk kemasan wisata seperti gantungan kunci, hiasan dinding, tempat tisu dan lain-lain. Dengan begitu secara tidak langsung akan dapat meningkatkan produktivitas perajin sulam di Sumatera Barat sebagai salah satu daerah sentra industri kreatif.

\section{TINJAUAN PUSTAKA}

Penelitian sebelumnya yang relevan

Studi tentang seni kerajinan sulam Koto Gadang dalam bentuk penelitian sudah pernah dilakukan, baik perseorangan (diri sendiri, orang lain ) maupun instansi yang berkompeten antara lain taman budaya, museum, dan perguruan tinggi seni dibidang seni rupa. Penelitian yang berhubungan langsung dengan peningkatan kreatifitas perajin sulam Koto Gadang melalui pengembangan desain motif menuju industri kreatif belum ditemukan. Adapun tinjauan hasil penelitian yang terkait atau berdekatan dengan penelitian ini dapat diperoleh dari hasil penelitian, jurnal dan buku-buku antara lain:

Penelitian Ranelis yang dimuat dalam jurnal Ekspresi Seni jurnal Ilmu Pengetahuan dan Karya Seni (2009) yang berjudul Sulaman Koto Gadang Kajian Bentuk dan Fungsi Sosial. Di dalamnya menjelaskan tentang kerajinan sulam Koto Gadang. Bentuk produk, motif dan proses pembuatan dari produk kerajinan sulaman Koto Gadang serta pembuatan sulaman dengan teknik suji cair dan tusuk kepala peniti. Di dalamnya juga menjelaskan tentang penempatan motif sulaman yang terdapat pada selendang wanita Koto Gadang apakah itu selendang pengantin, selendang wanita yang masih muda dan wanita yang sudah tua. Penempatan motif sulam pada pakaian pengantin laki-laki, dan pada tempat rokok pengantin laki-laki Koto Gadang.

Penelitian Ranelis dan kendall Malik yang dimuat dalam jurnal ideology seni Karya Seni (2018), Pengembangan desain produk dan sulam Koto Gadang. Di dalamnya menguraikan tentang kerajinan sulam yang ada di Koto Gadang terutama kerajinan Denny \& Desi dan kerajinan sulam Amai Setia yang merupakan perintis utama organisasi perempuan yang ada di Koto Gadang. Penelitian ini juga menjelaskan tentang produk sulam Koto Gadang yang kreatif dan inovatif dalam bentuk produk pelengkap rumah tangga, teknik dan proses pembuatan kerajinan sulam Kota Gadang. 


\section{Desain dan kreativitas}

Artikel ilmiah yang berjudul " Desain Mebel dalam Pendidikan Seni dan Desain" yang ditulis oleh Laksmi Kusuma Wardani pada jurnal Dimensi Interior. Didalamnya menjelaskan tentang predikat baik sebuah desain tergantung pada sasaran dan filosofi desain, sasaran berbeda-beda sesuai dengan kebutuhan dan kepentingan dan upaya mendesain berorientasi .ntuk mencapai hasil optimal dengan biaya yang rendah, dengan cara memperhatikan: 1). Faktor kenyamanan, kepraktisan, keselamatan, kemudahan dalam penggunaan, kemudahan dalam pemeliharaan dan kemudahan dalam perbaikan; 2). Faktor Fungsi yaitu faktor kelayakan, keandalannya, struktur, dan pengguna; 3) Faktor Pemasaran yaitu sesuai dengan selera konsumen, citra produk, sasaran pasar dan penentuan harga; 4).Kepentingan produsen yaitu identitas produsen, status, daya tarik dan nilai estetis.

Penelitian Ranelis dan Desi Trisnawati (2012) yang berjudul Kerajinan Bordir Hj. Rosma IV Angkek Canduang Kajian Desain, Fungsi Personal dan Fungsi Fisik. Penelitian ini di dalamnya memuat tentang kajian desain yang melipurti kajian strategi desain, strategi inovasi, dan strategi pasar. Fungsi produk bordir $\mathrm{Hj}$. Rosma.

\section{METODE PENELITIAN}

Metode penelitian merupakan cara ilmiah untuk memahami objek penelitian, dengan mengikuti langkah-langkah yang dapat memandu peneliti sesuai prosedur penelitian yang akan dilakukan. Metode utama yang digunakan dalam penelitian ini adalah metode eksperimen. Data yang diperlukan adalah data tentang budaya tradisional Koto Gadang dan kondisi kerajinan sulam Koto Gadang. Data yang diperlukan itu dikumpulkan dengan metode obsevasi, studi pustaka, dan wawancara. Data-data tersebut diolah dan diinterpretasikan sehingga ditemukan konsep-konsep rancangan desain, yang menjadi dasar dalam melakukan eksperimen desain di laboratorium atau studio tempat melakukan eksperimen rancangan produk dan motif sulam.

\section{Jenis Penelitian}

Secara khusus penelitian yang dilakukan menggunakan metode penelitian kualitatif untuk mengungkap fenomena yang ada di lapangan. Dalam mengkaji pengembangan desain produk dan motif sulam ini menggunakan kajian strategi desain yang terdiri dari strategi desain dan strategi inovasi yang dikemukakan oleh Agus Sachari, dan teori lain yang terdiri dari daya tarik keindahan produk, bahan-bahan yang digunakan, alat yang dipakai, teknik pembuatan dan keaslian produk. Proses penelitian ini dilakukan dalam dua tahap yang dibagi dalam empat langkah yaitu eksplorasi, perancangan, perwujudan dan evaluasi (Gustami, 2004).

\section{Eksplorasi}

Penelitian pada tahap ini adalah eksplorasi dilakukan dengan cara menggali sumber-sumber ide dengan cara, (1) Penggalian informasi dan melakukan studi pustaka melalui buku, majalah, koran, dokumen, yang berkaitan dengan budaya daerah Koto Gadang. (2) Obsevasi yakni menelusuri sumber-sumber visual produk sulam Koto Gadang yang lama dan yang baru. (3) Perenungan dengan cara mengolah informasi atau data yang diperoleh dari hasil studi pustaka, dan observasi. Pada tahap ini akan ditelusuri dan diidentifikasi berbagai jenis desain motif yang terdapat pada produk sulam Koto Gadang sebagai bahan perbandingan nantinya.

Target atau indikator pada tahap eksplorasi ini adalah: 1) ditemukan paling sedikit lima desain motif sulam yang kreatif dan inovatif dengan ciri khas Minangkabau, dan memiliki nilai crafmansive; 2) ditemukan paling sedikit delapan desain busana yang terdiri dari dua desain busana kerja wanita, dua desain busana muslim pria, empat desain busana muslim wanita; 3) ditemukan paling sedikit lima konsep desain pelengkap busana yaitu jilbab, tas, dompet, peci dan selendang. Semua konsep desain tersebut mempertimbangkan ornamen tradisional sebagai motif hias pada produk sulam yang dihasilkan daerah Koto Gadang. Temuan pada tahap ini yang berupa konsep-konsep verbal akan disajikan secara deskriptif dan selanjutnya akan divisualisasikan melalui serangkaian eksperimen desain.

\section{Perancangan}

Aktifitas yang dilakukan pada tahap ini adalah hasil temuan data deskriptif dituangkan ke dalam bentuk visual, berupa desain-desain alternatif, baik model-model desain busana maupun desain-desain aksesoris busana. Dari sejumlah desain-desain alternatif yang berhasil dibuat kemudian ditentukan beberapa yang terbaik sebagai rancangan desain terpilih, yang kemudian diwujudkan kedalam gambar kerja. Aspek-aspek yang dipertimbangkan pada saat perancangan adalah bahan, alat, proses, variasi bentuk, ukuran, unsur estetik, dan prospek pasar.

Target atau indikator keberhasilan dari tahap ini adalah terciptanya paling sedikit delapan desain busana, lima jenis desain pelengkap busana, dan lima desain cenderamata, dengan motif kreatif dalam bentuk gambar kerja sesuai dengan ide, dan siap diwujudkan menjadi karya yang akan diaplikasikan dalam pembuatan produk sulaman.

\section{Perwujudan}

Aktivitas penelitian pada tahap ini adalah Tahap perwujudan dilakukan dengan mewujudkan desain atau gambar kerja ke dalam bentuk rancangan busana, pelengkap (asesoris) busana dan produk cenderamata dengan desain motif yang kreatif dan inovatif. Kegiatan ini dilakukan melalui beberapa tahap yaitu (1) persiapan alat dan bah- 
an, (2) pembuatan motif-motif hias yang akan diterapkan dengan teknik sulam Koto Gadang, (3) pembuatan pola, (4) memindahkan pola ke kain yang akan disulam, (5) memindahkan motif ke kain sesuai dengan bentuk produk, (6) proses menyulam kain sesuai motif, (7) menggunting kain sesuai dengan pola dan kerangka, (8) menggabungkan masing-masing pola sesuai dengan produk yang dibuat dengan cara dijahit, (9) proses finishing untuk memperindah produk sulam yang dihasilkan. (10) penyajian karya dengan cara berpameran. Target atau indikator keberhasilan pada tahap ini adalah terwujudnya paling sedikit lima buah busana kerja, muslim, tiga produk asesoris busana dan dua produk cenderamata.

\section{Evaluasi dan publikasi}

Evaluasi bertujuan untuk mengetahui secara menyeluruh kesesuaian antara gagasan (konsep) dan desain dengan hasil perwujudannya dan mengkritisi pencapaian dari desain produk. Kriteria yang digunakan dalam melakukan evaluasi adalah bentuk unik dan original dari desain yang dihasilkan (tanpa meniru desain yang telah ada). Ukuran proporsional, nilai fungsional, menyiratkan bentuk dan nilai seni budaya Sumatera Barat dan memiliki prospek pasar yang menjanjikan.

Evaluasi melibatkan perajin sulam, pegusaha, dan konsumen. Evaluasi dilaksanakan serangkaian dengan kegiatan publikasi dalam bentuk pameran disertai dengan penyebaran katalogus produk hasil penelitian. Dari keempat tahapan tersebut, untuk penelitian ini difokuskan pada tahap eksplorasi dan tahap kedua yaitu tahap perancangan.

\section{PEMBAHASAN}

\section{Pengembangan Desain Motif dan Produk Kerajinan Sulam Koto Gadang}

Secara sistematis sesuai dengan metode dan tahap penelitian yang direncanakan, hasil penelitian dibagi dalam dua sub judul yaitu: 1) tahap eksplorasi yaitu membahas berbagai temuan yang digali dari berbagai sumber guna menemukan konsep-konsep desain: 2) tahap perancangan yang meliputi eksperimen desain hingga pembuatan rancangan final dalam bentuk gambar kerja. Pada kedua sub judul tersebut dibagi lagi menjadi sub-sub judul guna memfokuskan bahasan secara lebih spesifik sesuai dengan temuan-temuan yang dibahas.Munculnya ide-ide kesenian dan desain kreatif dipicu oleh beberapa faktor, diantaranya adalah pengalaman, pengamatan, keinginan unutk memecahkan suatu masalah, kajian terhadap referensi atau pustaka, tekanan atau keterdesakan, serta gabungan dari berbagai faktor itu. Karena itu, ide tidaklah muncul dari kekosongan atau hanya suatu kebetulan, akan tetapi buah dari pencarian yang gigih melalui penggalian dari berbagai sumber. Proses penemuan ide atau konsep kesenian atau desain kreatif yang demikian itu disebut sebagai tahap eksplorasi (Gustami, 2004 ). Eksplorasi dilakukan untuk menemukan konsep-konsep desain pada busana, asesoris busana dan produk cenderamata yang kreatif dan inofatif dengan menitikberatkan pada ragam hias Minangkabau dan motif sulam yang ada di Koto Gadang. Target atau indikator pada tahap eksplorasi ini adalah: 1) ditemukan 5 (lima) desain motif sulam yang kreatif dan inovatif dengan ciri khas Minangkabau, dan memiliki nilai crafmansive; 2) ditemukan paling sedikit 8 desain busana yang terdiri dari 2 desain busana kerja wanita, 2 desain busana muslim pria, 2 desain busana muslim wanita; 3) ditemukan pling sedikit 5 konsep desain pelengkap busana yaitu jilbab, tas, dompet, peci dan selendang. 3 desain produk cenderamata. Semua konsep desain tersebut telah mempertimbangkan ornamen tradisional sebagai motif hias pada produk sulam yang dihasilkan daerah Koto Gadang. Temuan pada tahap ini yang berupa konsep-konsep verbal akan disajikan secara deskriptif dan selanjutnya akan divisualisasikan melalui serangkaian eksperimen desain.

Bentuk motif- motif minangkabau dan motif kreasi dari perajin sulam Koto Gadang yang diterapkan dalam pengembangan desain motif dan produk sulam ini adalah:

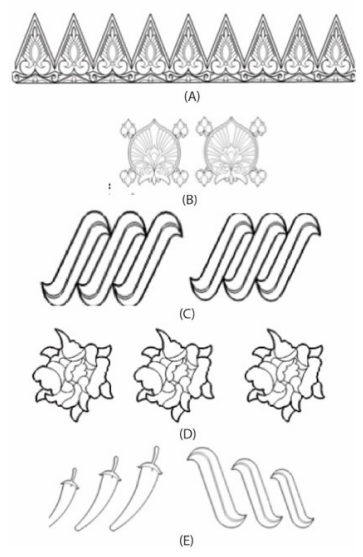

\footnotetext{
Gambar 1. (A) Motif Pucuak Rabuang, (B) Motif Sirih Gadang, (C) Motif Itiak Pulang Patang,

(D) Motif Bunga Mawar, (E) Motif Itiak Lado Hijau Sumber: Dokumentasi Penulis, 2018
}

Pengembangan desain produk kerajinan sulam Koto Gadang yang diberi hiasan motif Minangkabau dan kreasi perajin Sulam Koto Gadang antara lain:

\section{Desain busana kerja wanita motif pucuak rabuang}

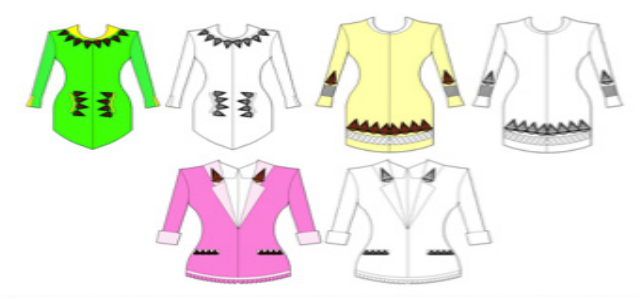

Gambar 2. Desain Busana Kerja wanita motif pucuak rabuang dan saik ajik (Sumber: Dokumentasi penulis, 2018) 
Desain busana kerja di atas merupakan wujud visualisasi dari konsep atau ide busana kerja. Bahan utama dalam pembuatan produk ini adalah kain oxvor. Ukuran yang digunakan adalah ukuran standar wanita dewasa. Desain yang ditampilkan sederhana namun tetap menunjukkan kewibawaan dan ciri khas wanita Minangkabau dengan hiasan kreasi motif Minangkabau yaitu motif pucuak rabuang dan saik galamai, yang disulam dengan teknik suji cair dan kapalo samek. Motif pucuak rabung ditempatkan pada bagian lengan, saku, krah baju dan bagian bawah baju kerja. Sedangkan motif saik ajik atau saik galamai ditempatkan pada bagian bawah baju dan pada bagian lengan bawah baju kerja. Diyakini dengan ditampilkannya rancangan desain busana kerja yang disulam dengan teknik sulam Koto Gadang ini akan menimbulkan nilai keindahan tersendiri dan memiliki prospek pasar yang lebih menjanjikan dan diminati oleh konsumen.

\section{Desain busana muslim wanita}
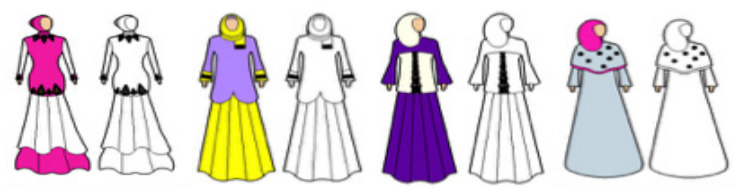

Gambar 3. Busana Muslim motif bunga mawar, sirih gadang, saik ajik dan pucuak rabuang

(Sumber: Dokumentasi penulis, 2018)

Desain busana muslim wanita ini dihiasi dengan motif tradisional minangkabau yaitu motif pucuak rabuang, saik ajik, sirih gadang dan motif kreasi perajin sulam Koto Gadang yaitu motif bunga mawar. Motif-motif tersebut ditempatkan pada bagian lengan, tengah, atas dan pada bagian bawah baju muslim. Desain busana muslim yang dibuat dapat digunakan dalam situasi apa saja, dapat digunakan sebagai busana kerja wanita ataupun untuk acara resmi lainnya. Teknik sulam yang ditempatkan pada busana ini adalah teknik suji cair dan kepala peniti. Warna yang digunakan untuk menyulam motif adalah warna yang disesuaikan dengan warna kain dasarnya. Teknik pemberian warna pada motif sulam menggunakan teknik gradasi warna yaitu dari warna tua ke warna yang lebih muda atau sebaliknya dari warna muda ke warna yang tua. Bahan dasar kain yang digunakan adalah kain boloteli. Ukuran yang digunakan untuk busana muslim wanita ini menggunakan ukuran standar wanita dewasa pada umumnya. Desain busana muslim yang dirancang ini memiliki keunikan dan keindahan tersendiri dari motif dan teknik sulam yang dihasilkan dari daerah Koto Gadang.

\section{Desain Busana muslim pria}

Desain busana muslim pria ini dihiasi dengan motif tradisional minangkabau yaitu motif pucuak rabuang, dan sirih gadang. Motif-motif tersebut ditempatkan pada bagian lengan, tengah, atas dan pada bagian saku baju muslim. Desain busana muslim yang dibuat dapat digunakan dalam situasi apa saja, dan dapat digunakan untuk acara resmi lainnya. Teknik sulam yang ditempatkan pada busana ini adalah teknik suji cair dan kepala peniti. Warna yang digunakan untuk menyulam motif adalah warna yang disesuaikan dengan warna kain dasarnya. Teknik pemberian warna pada motif sulam menggunakan teknik gradasi warna yaitu dari warna tua ke warna yang lebih muda atau sebaliknya dari warna muda ke warna yang tua. Bahan dasar kain yang digunakan adalah kain boloteli. Ukuran yang digunakan untuk busana muslim pria ini menggunakan ukuran standar pria dewasa pada umumnya. Desain busana muslim yang dirancang ini memiliki keunikan dan keindahan tersendiri dari motif dan teknik sulam yang dihasilkan dari daerah Koto Gadang.

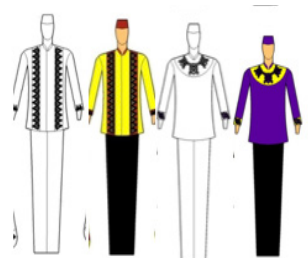

Gambar 4. Desain busana muslim pria motif pucuak rabuang dan sirih gadang (Sumber: Dokumentasi penulis 2018)

\section{Desain busana muslim keluarga}

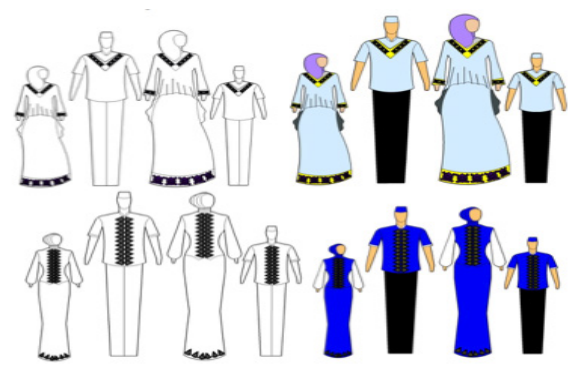

Gambar 5. Desain busana muslim keluarga motif pucuak rabuang dan sirih gadang

(Sumber: Dokumentasi penulis, 2018)

Desain busana muslim keluarga ini terdiri dari pakaian muslim untuk bapak, ibuk, anak perempuan dan pakaian muslim untuk anak laki-laki. Pakaian muslim keluarga ini dihiasi dengan motif tradisional minangkabau yaitu motif pucuak rabuang, dan sirih gadang. Motif-motif tersebut ditempatkan pada bagian lengan, tengah, krah dan pada bagian bawah rok baju muslim wanita. Desain busana muslim yang dibuat dapat digunakan dalam situasi apa saja, dan dapat digunakan untuk acara resmi lainnya. Teknik sulam yang ditempatkan pada busana ini adalah teknik suji cair dan kepala peniti. Warna yang digunakan untuk menyulam motif adalah warna yang disesuaikan dengan warna kain dasarnya. Teknik pemberian warna pada motif sulam menggunakan teknik gradasi warna yaitu dari warna tua ke warna yang lebih muda atau sebaliknya dari warna muda ke warna yang tua. Bahan dasar kain yang digunakan adalah kain boloteli. Ukuran yang digunakan untuk 
busana muslim ini adalah ukuran standar pria dewasa dan anak-anak. Ukuran standar wanita dewasa dan anak-anak pada umumnya. Desain busana muslim yang dirancang ini memiliki keunikan dan keindahan tersendiri dari motif dan teknik sulam yang dihasilkan dari daerah Koto Gadang.

\section{Desain Pelengkap busana wanita (jilbab pasmina)}
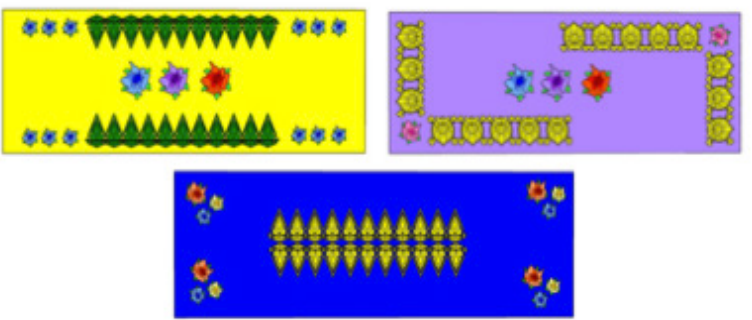

Gambar 6. Pasmina motif bunga mawar, pucuak rabuang, dan sirih gadang (Sumber: Dokumentasi penulis, 2018)

\section{Desain Pelengkap busana wanita (tas)}
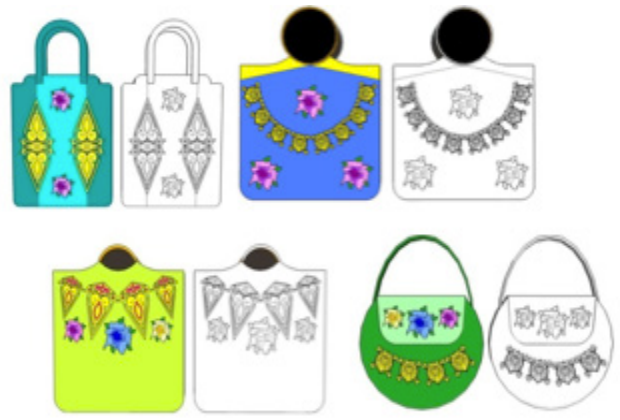

Gambar 7. Tas motif bunga mawar, pucuak rabuang, dan sirih gadang (Sumber: Dokumentasi penulis, 2018)

Desain pelengkap busana berupa tas ini munggunakan bahan kain belacu, beludru dan kain saten. Beberapa hasil rancangan desain tas, tampilannya diperindah dengan menempatkan motif minangkabau berupa motif sirih gadang dan pucuak rabuang serta motif hasil kreasi perajin sulam Koto Gadang yang sudah didapat secara turun-temurun. Pelengkap busana berupa tas ini dibuat dengan bentuk desain yang sederhana dan praktis, yang bertujuan tas ini nantinya tidak hanya digunakan dengan busana kerja tapi juga dapat dipadukan dengan busana muslim wanita. Teknik pemberian warna pada motif sulam menggunakan teknik gradasi warna yaitu dari warna tua ke warna yang lebih muda atau sebaliknya dari warna muda ke warna yang tua.

\section{Desain Pelengkap busana wanita (dompet)}

Dompet adalah pelengkap busana yang tidak terlepas dari rancangan busana wanita. Perancangan desain dompet ditemukan 6 rancangan desain yang sederhana dan tidak terlalu besar. Sehingga rancangan desain dompet ini dapat digunakan dalam berbagai kesempatan. Dompet ini dirancang dengan menggunakan motif Minangkabau yang di- sulam dengan sulam Koto Gadang. Motif-motif yang ditempatkan pada dompet ini adalah motif pucuak rabuang yang dikombinasikan dengan motif bunga mawar, motif sirih gadang yang dikombinasikan dengan motif bunga mawar dan motif itiak lado hijau. Motif ini akan disulam dengan teknik gradasi warna dari warna yang lebih tua kewarna yang lebih muda atau sebaliknya dari warna yang lebih muda kewarna yang lebih tua. Teknik sulam yang digunakan adalah teknik suji cair dan tusuk kepala peniti.

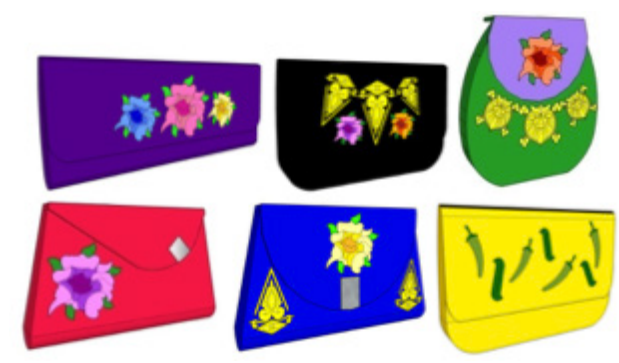

Gambar 8. Desain dompet wanita motif bunga mawar, pucuak rabuang, dan sirih gadang, itik lado hijau (Sumber: Dokumentasi penulis, 2018)

\section{Pelengkap busana pria (peci)}

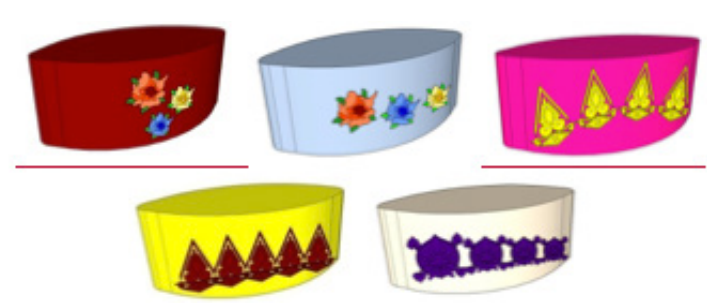

Gambar 9. Desain peci motif bunga mawar, pucuak rabuang, dan sirih gadang (Sumber: Dokumentasi penulis, 2018)

Peci adalah pelengkap busana muslim pria. Peci ini dirancang dengan menggunakan motif Minangkabau dan motif sulaman Koto Gadang itu sendiri sebagai hiasannya. Peci ini digunakan untuk pelengkap busana muslim pria. Peci ini dirancang dan diberi hiasan menggunakan motif Minangkabau yang disulam dengan sulam Koto Gadang. Motif-motif yang ditempatkan pada dompet ini adalah motif pucuak rabuang, motif bunga mawar, dan motif sirih gadang. Motif ini pewarnaannya dengan teknik gradasi warna dari warna yang lebih tua kewarna yang lebih muda atau sebaliknya dari warna yang lebih muda kewarna yang lebih tua. Teknik sulam yang digunakan adalah teknik suji cair dan tusuk kepala peniti.

\section{Desain produk cenderamata (gantungan kunci)}

Gantungan kunci adalah produk cenderamata yang biasanya banyak terdapat di objek-objek wisata. Gantungan kunci merupakan salah satu oleh-oleh yang praktis karena ukurannya yang kecil sehingga mudah untuk dibawa kemana saja. Gantungan kunci ini dibuat dan dihias den- 
gan sedikit sulaman. Perancangan desain gantungan kunci ini dibuat dengan bentuk yang sederhana. Gantungan kunci ini dihiasi dengan motif minangkabau yaitu pucuak rabuang, sirih gadang, rangkiang, jam gadang dan bentuk motif lainnya. Motif ini pewarnaannya dengan teknik gradasi warna dari warna yang lebih tua kewarna yang lebih muda atau sebaliknya dari warna yang lebih muda kewarna yang lebih tua. Teknik sulam yang digunakan adalah teknik suji cair dan tusuk kepala peniti.

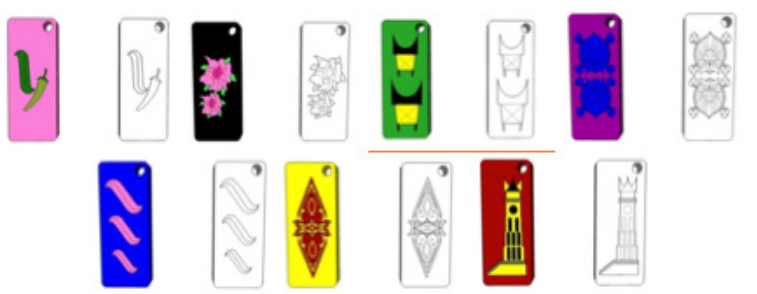

Gambar 10. Gantungan kunci motif bunga mawar, pucuak rabuang, itiak pulang patang, rangkiang, jam gadang dan sirih gadang. (Sumber: Dokumentasi penulis, 2018)

\section{Desain produk cenderamata (Tempat Tisu)}

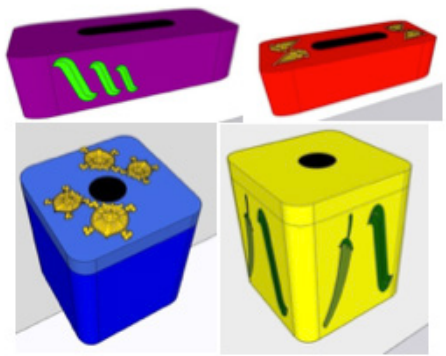

Gambar 11. Desain tempat tisu motif pucuak rabuang, itiak pulang patang, sirih gadang, dan itiak lado hijau.

Sumber: Dokumentasi penulis, 2018

Tempat tisu sama halnya dengan gantungan kunci adalah selain pelengkap kebutuhan sehari-hari, tempat tisu juga dapat dijadikan sebagai produk cenderamata yang biasanya juga terdapat di objek-objek wisata. Tempat tisu merupakan salah satu oleh-oleh yang praktis karena ukurannya yang kecil sehingga mudah untuk dibawa kemana-mana saja. Tempat tisu ini dibuat dan dihias dengan sedikit sulaman. Perancangan desain tempat tisu dibuat dengan dua model yaitu bentuk balok dan kubus dengan bentuk yang sederhana. Motif ini pewarnaannya dengan teknik gradasi warna dari warna yang lebih tua kewarna yang lebih muda atau sebaliknya dari warna yang lebih muda kewarna yang lebih tua. Teknik sulam yang digunakan adalah teknik suji cair dan tusuk kepala peniti.Tempat tisu ini dihiasi dengan motif minangkabau yaitu pucuak rabuang, sirih gadang, itiak pulang patang dan itiak lado hijau.

\section{Desain produk cenderamata (Hiasan Dinding)}

Hiasan dinding dapat dijadikan sebagai produk cendera- mata yang biasanya juga terdapat di objek-objek wisata. Hiasan dinding merupakan salah satu oleh-oleh yang disukai oleh wisatawan. Hiasan dinding yang penulis ciptakan ukurannya tidak terlalu besar karena mempertimbangkan kepraktisan orang yang membawanya. Hiasan dinding dibuat dan dihias dengan motif minangkabau yang diberi sulaman. Hiasan dinding ini dibuat dengan bentuk geometris yaitu lingkaran, segi tiga, segi empat, segi lima, segi enam dan oval. Hiasan dinding ini dihiasi dengan motif minangkabau yaitu pucuak rabuang, sirih gadang, dan motif minangkabau lainnya dengan cara disulam. Motif ini pewarnaannya dengan teknik gradasi warna dari warna yang lebih tua kewarna yang lebih muda atau sebaliknya dari warna yang lebih muda kewarna yang lebih tua. Teknik sulam yang digunakan adalah teknik suji cair dan tusuk kepala peniti.

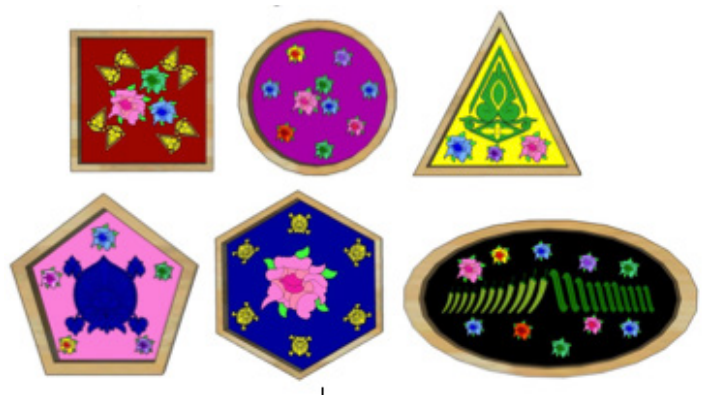

Gambar 12. Desain hiasan dinding motif bunga mawar, sirih gadang, itiak lado hijau, itiak pulang patang, dan pucuak rabuang (Sumber: Dokumentasi penulis, 2018)

\section{Desain produk cenderamata ( Tempat Koin )}
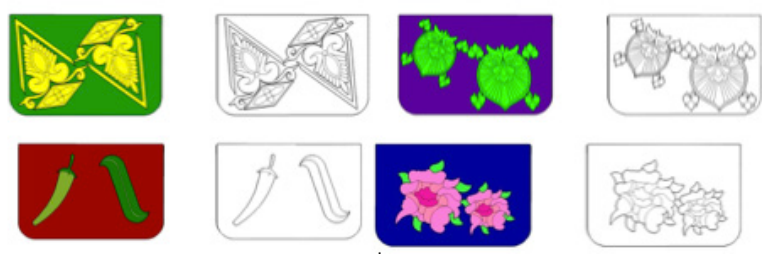

Gambar 13. Desain tempat koin motif bunga mawar, pucuak rabuang, dan sirih gadang, itik lado hijau

(Sumber: Dokumentasi penulis, 2018)

Tempat koin sama halnya dengan gantungan kunci, tempat tisu, dan hiasan dinding fungsinya selain pelengkap kebutuhan sehari-hari, tempat koin juga dapat dijadikan sebagai produk cenderamata yang biasanya juga terdapat di objek-objek wisata. Tempat koin merupakan salah satu oleh-oleh yang praktis karena ukurannya yang kecil sehingga mudah untuk dibawa kemana-mana saja. Tempat koin ini dibuat dan dihias dengan sedikit sulaman. Tempat koin ini dihiasi dengan motif minangkabau yaitu pucuak rabuang, sirih gadang, bunga mawar, dan motif itiak lado hijau. Motif ini pewarnaannya dengan teknik gradasi warna dari warna yang lebih tua kewarna yang lebih muda 
atau sebaliknya dari warna yang lebih muda kewarna yang lebih tua. Teknik sulam yang digunakan adalah teknik suji cair dan tusuk kepala peniti.

\section{Desain produk cenderamata ( Tempat kartu )}
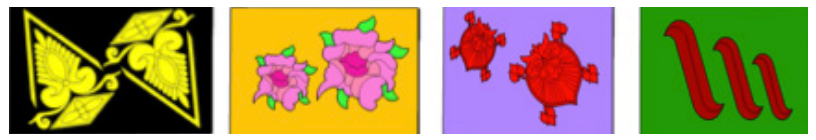

Gambar 14. Desain tempat kartu motif bunga mawar, pucuak rabuang, itiak pulang patang dan sirih gadang.

(Sumber: Dokumentasi penulis, 2018)

Tempat kartu sama halnya dengan gantungan kunci dan tempat koin selain pelengkap kebutuhan sehari-hari, tempat kartu juga dapat dijadikan sebagai produk cenderamata yang biasanya juga terdapat di objek-objek wisata. Tempat kartu merupakan salah satu oleh-oleh yang praktis karena ukurannya yang kecil sehingga mudah untuk dibawa kemana-mana saja. Tempat kartu ini dibuat dan dihias dengan sedikit sulaman. Tempat kartu ini dihiasi dengan motif minangkabau yaitu pucuak rabuang, sirih gadang, dan itiak pulang patang. Motif ini pewarnaannya dengan teknik gradasi warna dari warna yang lebih tua kewarna yang lebih muda atau sebaliknya dari warna yang lebih muda kewarna yang lebih tua. Teknik sulam yang digunakan adalah teknik suji cair dan tusuk kepala peniti.

\section{SIMPULAN}

Berdasarkan permasalahan, tujuan, dan pembahasan dapat disimpulkan, bahwa untuk meningkatkan kualitas kerajinan sulam yang dibuat oleh perajin sulam Koto Gadang perlu adaya peningkatan desain motif dan produk yang baru yang kreatif dan inovatif. Melalui tahap perancangan dan eksplorasi. Eksplorasi terhadap motif-motif tradisional Minangkabau. Dari hasil eksplorasi ornamen tradisional Minangkabau dapat menghasilkan beberapa konsep desain busana kerja wanita, desain busana muslim pria, pelengkap busana wanita dan pria, serta produk cenderamata. Konsep-konsep penciptaan desain tersebut dapat dirancang desain visual melalui eksperimen desain-desain alternatife, desain terpilih, dan pembuatan desain produksi. Berdasarkan eksperimen yang dilakukan dapat diciptakan beberapa buah desain busana yaitu desain busana kerja wanita, busana muslim wanita dan busana muslim pria. Desain pelengkap busana wanita berupa jilbab pasmina, dompet, dan tas. Pelengkap busana pria yaitu peci. Sedangkan untuk produk cenderamata adalah gantungan kunci, hiasan dinding, tempat tisu, tempat kartu dan tempat koin.

Eksperimen untuk memvisualisasikan desain-desain tersebut dibuat dalam bentuk desain-desain alternatife dan desain terpilih, yang menghasilkan tiga buah desain busana kerja wanita, empat desain busana muslim wanita dan empat desain busana muslim pria, tiga desain busana muslim keluarga, tiga desain pelengkap busana jilbab pasmina, enam desain dompet, empat desain tas, dan lima desain peci. Produk cenderamata tempat tisu empat buah desain, tempat kartu empat buah desain, tempat koin empat buah desain, gantungan kunci tujuh buah desain dan enam desain hiasan dinding. Desain-desain yang dirancang telah mempertimbangkan keserasian, keindahan, nilai fungsional, dan prospek pasar.

Rancangan desain-desain busana, pelengkap busana dan produk cenderamata dihias dengan menerapkan motif Minangkabau yang disulam dengan teknik suji cair dan kepala peniti sebagai ciri khas sulam Koto Gadang. Motif ini pewarnaannya dengan teknik gradasi warna dari warna yang lebih tua kewarna yang lebih muda atau sebaliknya dari warna yang lebih muda kewarna yang lebih tua. Dengan adanya rancangan desain motif dan produk baru dari sulam Koto Gadang akan mendapat apresiasi sehingga kerajinan sulam Koto Gadang akan lebih banyak diketahui dan diminati oleh masyarakat dan berdampak positif dalam pengembangan industr kreatif di Sumatera Barat khususnya disektor bidang kerajinan.

\section{UCAPAN TERIMAKASIH}

Tim peneliti mengucapkan terimakasih kepada kemenristekdikti, melalui LPPMPP ISI padangpanjang atas bantuan dana yang diberikan untuk melaksanakan penelitian ini, melalui dana penelitian terapan unggulan perguruan tinggi dengan perjanjian/kontrak pelaksanaan penugasan penelitian terapan Nomor: 003/SP2H/LT/DRPM/2018 Tanggal 12 Maret 2018.

\section{DAFTAR RUJUKAN}

Alisyabana, Sutan Takdir. (1983), Kreatifitas, penerbit Dian Rakyat, Jakarta.

Esde, Erni, et al. (1994-1995), Kerajinan Sulaman Sumatra Barat, Musium Negeri Sumatra Barat "Adhityawarman”, Departemen Pendidikan Dan Kebudayaan, Padang.

Yanuarni, Dini. (2009), Sulaman Tangan Amai Setia Koto Gadang Bukittinggi : Kajian Filosofi dan Fungsi, Jurnal Ekspresi Seni Ilmu Pengetahuan dan Karya Seni ISI Padangpanjang, edisi Mei 2009, ISI Padangpanjang, Padangpanjang.

Marah, Risman, Ragam Hias Minangkabau. (1987-1988), Departemen Pendidikan dan Kebudayaan Direktorat Jendral Kebudayaan, Jakarta.

Navis, Ali Akbar. (1984), Alam Terkembang Jadi Guru "Adat dan Kebudayaan Minangkabau, PT Grafiti Pres, Jakarta. 
Desi Indiana Ni Luh, Pande Sarjani Ni Ketut. (2018), Inovasi Desain Kemasan Ayam Betutu Sebagai Ikon OlehOleh Khas Bali Di Kota Denpasar,Mudra Jurnal Seni Budaya ISI Denpasar, edisi Februari 2018, ISI Denpasar

Ranelis. (2008), Kerajinan Sulam Koto Gadang Bukittinggi Sumatera Barat kajian Bentuk Dan Fungsi Sosial, (Tesis), ISI Yogyakarta, Yogyakarta,

(2009), Kerajinan Sulam Koto Gadang Kajian Bentuk dan Fungsi Sosial, Jurnal Ekspresi Seni Ilmu Pengetahuan dan Karya Seni ISI Padangpanjang, edisi Mei 2009, ISI Padangpanjang, Padangpanjang.

(2013), "Kerajinan Bordir Hj. Rosma Kajian Desain, Fungsi Personal dan Fungsi Fisik", Laporan Penelitian, ISI Padangpanjang, Padangpanjang.

Razni, Sita Dewi, Mity J. Juni, dan Rebecca Dahlan. (2005), Pakaian Tradisional Koto Gadang, Penerbit Yayasan Kerajinan Amai Setia, Bukittinggi.

\& Juni Mity j. (2011), Pakaian Tradisional

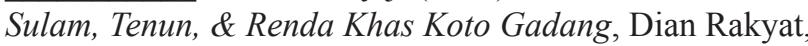
Jakarta.

Sachari Agus. (1986). Paradikma Desain Indonesia Pengantar dan Kritik, CV Rajawali, Jakarta.

Tokio, M. Soegeng. (1987), Mengenal Ragam Hias Indonesia, Angkasa Bandung, Bandung.

Wina Herdiana, Theresia Firstianti Santoso .(2018), Perancangan Souvenir Beridentitas Tradisi Telingaan Arau Khas Suku Dayak, Mudra Jurnal Seni Budaya ISI Denpasar, edisi Mei 2018, ISI Denpasar. 